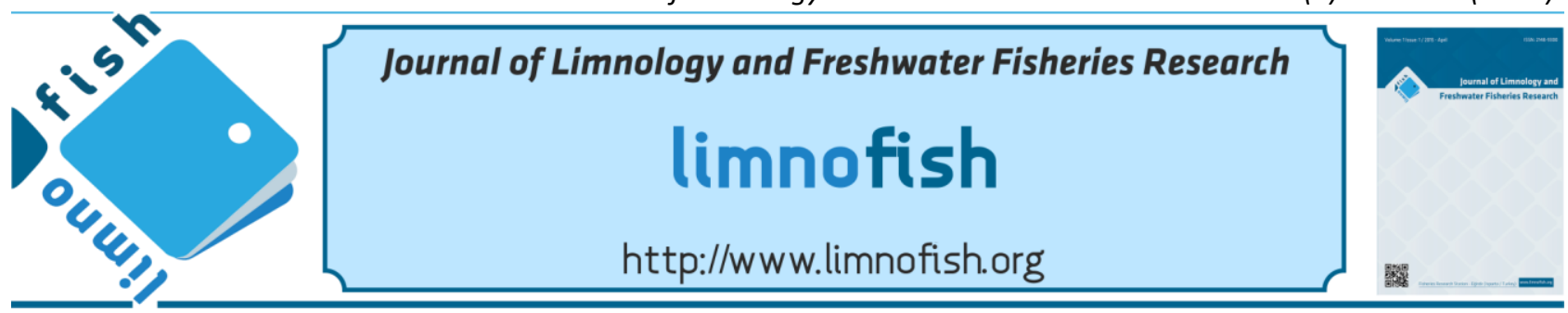

\title{
Dietary Replacement Effects of Maize with Graded Levels of Melon Shell on Growth Performance of Clarias gariepinus Fingerlings (Burchell, 1822)
}

\author{
Stanley Chidi IHEANACHO*1(D), Shedrack NWORU $^{2}(\mathbb{D})$ Emmanuel Okechukwu OGUEJI ${ }^{1}$, \\ Abubakar Jerma YAJI ${ }^{3}$ iD, Christian Emeka MBAH ${ }^{4}$ Emmanuel Anayo OKAFOR ${ }^{5}$ id \\ ${ }^{1}$ Department of Fisheries and Aquaculture, Federal University Ndufu Alike Ikwo, Ebonyi State, Nigeria \\ ${ }^{2}$ Department of Fisheries and Aquaculture, Ebonyi State University, Abakaliki, Ebonyi State, Nigeria \\ ${ }^{3}$ Department of Fisheries, Modibbo Adama University of Technology, Adamawa State, Nigeria \\ ${ }^{4}$ Department of Zoology, Ahmadu Bello University Zaria, Kaduna State, Nigeria \\ ${ }^{5}$ Department of Animal Science and Technology, Nnamdi Azikiwe University Awka, Anambra State, Nigeria
}

\section{A B STRACT}

A 60-day study was conducted to investigate the dietary effect of replacement of maize with graded levels of melon shell meal (MSM) on growth performance of Clarias gariepinus fingerling. Five isonitrogenous diets were formulated. MSM was added to the diet to replace maize at graded levels; $0 \%, 25 \%, 50 \%, 75 \%$ and $100 \%$. Total of 150 fish $(3.40 \pm 0.05 \mathrm{~g})$ were randomly assigned to the five treatment diets. Each treatment contained 10 fish per tank and each treatment was triplicated in a completely randomised design (CRD). Fish were fed twice daily at $5 \%$ body weight in equal proportions. Results showed significant differences $(\mathrm{P}<0.05)$ for measured growth parameters. Fish fed diet containing 100\% MSM had the highest mean weight gain $(70.70 \pm 4.62 \mathrm{~g})$, specific growth rate $(S G R)$ $(5.06 \pm 0.10 \%)$, best feed conversion ratio $(F C R)(0.54 \pm 0.04 \%)$ and protein efficiency ratio $(P E R)(1.68 \pm 0.11 \%)$ compared to other treatments and the control while fish fed $25 \% M S M$ had the poorest values for $M W G(39.88 \pm 4.37 \mathrm{~g}), S G R$ (4.20 \pm 0.16$), F C R(0.60 \pm 0.02)$ and PER $(0.95 \pm 0.11)$. MSM inclusion in diet of $C$. gariepinus up to $100 \%$ enhanced growth.

Keywords: Melon-shell, Replacement, Maize, Growth, C. gariepinus
ARTICLE INFO

\section{RESEARCH ARTICLE}

$\begin{array}{lll}\text { Received } & : 30.06 .2017 \\ \text { Revised } & : 21.10 .2017 \\ \text { Accepted } & : 31.10 .2017 \\ \text { Published } & : 29.12 .2017\end{array}$

DOI: 10.17216/LimnoFish.324412

\section{* CORRESPONDING AUTHOR}

stanley.iheanacho@funai.edu.ng

Phone: +2348063279905

How to Cite

Iheanacho SC, Nworu S, Ogueji EO, Yaji AJ, Mbah CE, Okafor EA. 2017. Dietary Replacement Effects of Maize with Graded Levels of Melon Shell on Growth Performance of Clarias gariepinus Fingerlings (Burchell, 1822) LimnoFish. 3(3):153-158. doi: 10.17216/LimnoFish.324412

\section{Introduction}

The consumption and demand for fish as a cheap source of animal protein is increasing in Africa. In most countries, vast majority of the fish supply comes from the rivers as captured fisheries. FAO (2004) in "The State of the World Fisheries and Aquaculture" concluded that developments in world fisheries and aquaculture during recent years have continued to follow the trends that were already becoming apparent at the end of the 1990s, as capture fisheries production is stagnating and aquaculture output is expanding faster than any other animalbased food sector. Thus development policies increasingly perceive aquaculture as means for economic growth and prospect for future fish supply (FAO 2004). According to FAO (2006), fish supplies from capture fisheries can no longer meet the growing global demand for aquatic foods. Hence, there is a need for a viable alternative fish production system that can sufficiently meet this demand, and aquaculture fits exactly into this role. As aquaculture production becomes more intensive in Nigeria, fish feed will be a significant factor in increasing productivity and profitability (Akinrotimi et al. 2007). Jamiu and Ayinla (2003) opined that feed management determines the viability of aquaculture as it accounts for at least $60 \%$ of the cost of fish production.

Maize is one of the conventional feedstuffs, thus a major source of metabolisable energy in most compounded diets for catfish as it is readily digestible by fish (Olurin et al. 2006). FAO (2005) reported that 
maize, which is predominantly used for human consumption in Nigeria, is not provided in sufficient quantities. The use of maize in fish feeds is becoming increasingly unjustified in economic terms (Tewe 2004), because of the ever increasing cost. Therefore, there is a need to exploit cheaper energy sources to replace expensive cereals in fish feed formulation. For the purpose of nutritional and economic benefits, previous researchers have attempted to increase the use of non-conventional feed resources to replace conventional feed ingredients like maize and fishmeal in fish diet (Olatunde 1996; Baruah et al. 2003; Eyo 2005). To relieve the feed competition between man and animal and for profit maximization, melon shell appears to be very appropriate for this purpose.

Melon husks are shells that are discarded after processing or shelling of melon seeds (Citrullus vulgaris). Melon is a cucurbit crop belonging to the family cucurbitaceae (Abiodun and Adeleke 2010). Melon (seed) crops are grown, harvested and processed in large tonnage in Nasarawa Local Government Area of Nasarawa as well as Kaduna State, Nigeria. The seeds are removed from the fruit, washed, sun-dried and sold in large quantities (tonnage) annually for commercial purpose (as a special soup condiment). They are also used as domestic remedy for urinary tract infection, hepatic congestion, intestinal worms and abnormal blood pressure (Moerman 1998). The freshly shelled seeds were reported contained $34.24 \%$ crude protein, $45.95 \%$ fat, $7.18 \%$ crude fibre, $4.05 \%$ ash, $8.03 \%$ moisture and $0.56 \%$ carbonhydrate (Fagbohun et al. 2011). However, large quantities of the melon husks are discarded and burnt, which pollute the environment (Ogbe and George 2012). While the fisheries industry is threatened with acute shortage of conventional feed ingredients leading to low productivity, it may be possible to utilize melon husks as non-conventional source of feed ingredient for fish. The current study seeks to investigate the effect of varying dietary inclusion levels of MSM in replacement of maize on growth performance of C. gariepinus.

\section{Materials and Methods \\ Experimental fish}

Fingerlings of $C$. gariepinus were procured from Regina Pacie fish farm in Abakaliki and transported to the Department of Fisheries and Aquaculture laboratory in a 50 litre and opened at the top within 20-30 minutes. Fish were subsequently subjected to a 2 min bath with $0.05 \%$ potassium permanganate $\left(\mathrm{KMnO}_{4}\right)$ to prevent skin infections. The fish were acclimatized for two weeks in a tarpaulin tank $(10 \mathrm{~m} \times 10 \mathrm{~m} \times 2 \mathrm{~m})$ and fed ad libitum on a daily basis with commercial feed (Coppens International Helmond Netherlands) containing $45 \%$ crude protein.

\section{Collection and processing of melon shell}

Melon shells were collected from the rural women who process melon seeds for commercial purpose (also called "egusi" by the people); they were sundried (3-4 days) and milled to powdered form using manual grinding machine at Abakaliki main market to aid incorporation with other feed ingredient. The milled melon shell was incorporated directly with other finely ground feedstuffs, pelletized, sundried and individual diets were packed into separate bags and then stored in a cool and dry place.

\section{Experimental Diet}

Five (5) isonitrogenous diets ( $42 \%$ crude protein) were formulated to contain melon shell meal (MSM) at $0 \%(D 1)$ as control diet, $25 \%(D 2), 50 \%(D 3), 75 \%$ (D4) and $100 \%$ (D5) in the diet of the experimental fish. Pearson's square method was used in feed formulation (De Silva and Anderson 1995). Feed ingredients for the experimental diet include soya bean meal $(S B M)$, groundnut cake $(G N C)$, maize meal $(M M)$, fish meal $(F M)$, melon shell meal $(M S M)$, methionine, lysine, vitamin/mineral premix, oil, salt and starch (binder) (Table 1). The formulation was based on gross proximate composition of the ingredients.

Table 1. Gross composition of experimental diets (g/2000g) containing melon shell meal fed to Clarias gariepinus

\begin{tabular}{lccccc}
\hline Ingredient & $\begin{array}{c}\mathrm{D} 1 \\
(0 \%)\end{array}$ & $\begin{array}{c}\mathrm{D} 2 \\
(25 \%)\end{array}$ & $\begin{array}{c}\mathrm{D} 3 \\
(50 \%)\end{array}$ & $\begin{array}{c}\mathrm{D} 4 \\
(75 \%)\end{array}$ & $\begin{array}{c}\mathrm{D} 5 \\
(100 \%)\end{array}$ \\
\hline$F M$ & 548 & 548 & 548 & 548 & 548 \\
$S B M$ & 390 & 390 & 390 & 390 & 390 \\
$G N C$ & 402 & 402 & 402 & 402 & 402 \\
$M M$ & 460 & 345 & 230 & 115 & - \\
$M S M$ & - & 115 & 230 & 345 & 460 \\
$B M$ & 40 & 40 & 40 & 40 & 40 \\
Vit. premix & 50 & 50 & 50 & 50 & 50 \\
Methionine & 15 & 15 & 15 & 15 & 15 \\
Lysine & 15 & 15 & 15 & 15 & 15 \\
Starch & 50 & 50 & 50 & 50 & 50 \\
Vegetable oil & 20 & 20 & 20 & 20 & 20 \\
Salt & 10 & 10 & 10 & 10 & 10 \\
\hline
\end{tabular}

$\overline{F M}$ - Fish meal, SBM - Soybean meal, GNC - Groundnut cake, $M M$ - Maize meal, MSM - Melon shell meal, $B M$ - Bone meal, $V t$ - Vitamin premix.

Proximate Composition of MSM and Experimental diets

Samples of MSM and experimental diets were sent to the International Institute for Tropical Agriculture (IITA) Laboratories Ibadan. Samples 
were analysed chemically according to the official methods of analysis described A.O.A.C. (2000). All analysis was carried out in triplicate. Proximate composition of the MSM and experimental diets are presented in Table 2. Result showed that MSM has $14.88 \% \mathrm{CP}, 7.16 \%$ moisture, $6.98 \%$ ash and $5.67 \%$ crude fibre.

Table 2. Proximate composition of experimental diets and $\operatorname{MSM}(\%)$

\begin{tabular}{lcccccc}
\hline Parameters & $\boldsymbol{M S M}$ & $\begin{array}{c}\mathrm{D} 1 \\
(0 \%)\end{array}$ & $\begin{array}{c}\mathrm{D} 2 \\
(25 \%)\end{array}$ & $\begin{array}{c}\mathrm{D} 3 \\
(50 \%)\end{array}$ & $\begin{array}{c}\mathrm{D} 4 \\
(75 \%)\end{array}$ & $\begin{array}{c}\mathrm{D} 5 \\
(100 \%)\end{array}$ \\
\hline Moisture & 7.16 & 5.46 & 5.40 & 5.37 & 5.08 & 5.00 \\
Crude fat & 3.16 & 4.29 & 4.25 & 4.37 & 4.16 & 4.15 \\
Crude ash & 6.98 & 10.24 & 10.73 & 11.35 & 10.83 & 11.33 \\
Crude fibre & 5.67 & 2.66 & 2.71 & 2.57 & 2.65 & 2.71 \\
Crude protein & 14.88 & 43.27 & 43.97 & 44.25 & 44.28 & 44.38 \\
NFE & 62.15 & 34.08 & 32.94 & 32.09 & 33.00 & 32.43 \\
G. Energy (kj/g) & 15.76 & 17.15 & 18.00 & 17.97 & 18.05 & 17.97 \\
\hline
\end{tabular}

G. Energy $=$ Gross Energy. NFE - Nitrogen Free Extract $=100$ (C. fat + C. $P+C$. Fibre + Ash + Moisture $), M S M=$ Melon Shell Meal

\section{Experimental design}

A total of one hundred and fifty (150) fingerlings with an average weight $3.40 \pm 0.50 \mathrm{~g}$ were randomly assigned to fifteen experimental aquaria tanks $(1 \mathrm{~m} \times 1 \mathrm{~m} \times 1 \mathrm{~m})$. Fish were subjected to five test diets with varying dietary inclusion levels of melon shell as treatments. Each treatment contained 10 fish and was triplicated in a completely randomised design $(C R D)$. Fish were fed twice daily (9:00 am and 4:00pm) at $5 \%$ body weight for 60 days. Total fish weight in each tank was determined at two weeks intervals and the amount of diet was adjusted accordingly.

\section{Water quality management}

Water in the experimental tank was removed every three days and replaced with fresh water in order to prevent water fouling and also remove fish faecal waste. Physicochemical analysis of water was measured once a week during the study (Table 3). The following parameters were tested; water temperature, $\mathrm{pH}$, and total dissolved solids (Turbidity) and dissolved oxygen $(D O)$ using a water testing kit (Pro-lab ${ }^{\mathrm{TM}}$, Florida).

Table 3. Water quality parameters of the experimental tank water.

\begin{tabular}{cccc}
\hline Parameter & DO $(\mathrm{mg} / \mathrm{l})$ & $\mathrm{pH}$ & Temp. $\left({ }^{\circ} \mathrm{C}\right)$ \\
\hline D1 & $6.83 \pm 0.17^{\mathrm{a}}$ & $6.67 \pm 0.17^{\mathrm{a}}$ & $27.67 \pm 0.33^{\mathrm{a}}$ \\
D2 & $6.83 \pm 0.17^{\mathrm{a}}$ & $6.83 \pm 0.17^{\mathrm{a}}$ & $27.33 \pm 0.33^{\mathrm{a}}$ \\
D3 & $6.67 \pm 0.17^{\mathrm{a}}$ & $6.50 \pm 0.29^{\mathrm{a}}$ & $28.00 \pm 0.00^{\mathrm{a}}$ \\
D4 & $6.67 \pm 0.17^{\mathrm{a}}$ & $6.67 \pm 0.17^{\mathrm{a}}$ & $27.67 \pm 0.33^{\mathrm{a}}$ \\
D5 & $6.36 \pm 0.15^{\mathrm{a}}$ & $6.32 \pm 0.08^{\mathrm{a}}$ & $28.67 \pm 0.33^{\mathrm{a}}$ \\
\hline
\end{tabular}

Means within column with different superscripts are significantly different $(\mathrm{P}<0.05)$.

\section{Growth parameters}

Growth were following Iheanacho et al. (2018) and Ogunji (2004);

Mean Weight Gain $(\mathrm{g})(M W G)$

$$
M W G=\frac{W T 2-W T 1}{N}
$$

Where $W t 1=$ initial mean weight of fish at time T1 $W t 2=$ final mean weight of fish at time $\mathrm{T} 2$ $N=$ Number of days

$$
\text { Feed Conversion Ratio (g) (FCR) }
$$

$$
F C R=\frac{\text { weight of feed given }(g)}{\text { Fish weight gain }}
$$

Relative Conversion Ratio ( $R C R)$

$$
R C R(\%)=\frac{(W f-W i)}{W i} \times 100
$$

$W f=$ final average weight at the end of the experiment

$W i=$ initial average weight at the beginning of the experiment

Protein Efficiency Ratio (PER)

Where;

$$
P E R=\frac{\text { Fish weight gain }(g)}{\text { Protein intake }(g)}
$$

Protein intake $=\frac{\left(\begin{array}{c}\% \text { protein } \\ \text { in feed }\end{array}\right) \times\left(\begin{array}{l}\text { total diet } \\ \text { consumed }\end{array}\right)}{100}$

Specific Growth Rate ( $S G R)$

$$
S G R=\frac{100\left(\log _{e} W f\right)-\left(\log _{e} W i\right)}{\text { Time }(\text { days })}
$$

$W f=$ final average weight at the end of the experiment

$W i=$ initial average weight at the beginning of the experiment

Loge $=$ Natural Logarithm reading

$$
\text { Survival rate }(\%)
$$

$$
\text { Survival Rate }(\%)=\frac{\left(\begin{array}{c}
\text { Number of } \text { fish } \\
\text { that survived }
\end{array}\right) \times 100}{\left(\begin{array}{c}
\text { Total number of } \\
\text { fish stocked }
\end{array}\right)}
$$

\section{Statistical Analysis}

Data collected from the experiment were subjected to one-way analysis of variance (ANOVA) using SPSS package version 20 and the differences among treatments were separated using Duncan multiple range test (Duncan 1955). 


\section{Results}

\section{Water Quality}

Water quality parameters recorded during the experiment are presented in Table 3. There was no significant difference $(\mathrm{P}>0.05)$ in all the parameters. The range for $\mathrm{pH}$ was observed to be between $6.32 \pm 0.08$ to $6.83 \pm 0.17$. Dissolved oxygen ranged between $6.36 \pm 0.15 \mathrm{mg} / \mathrm{L}-6.83 \pm 0.17 \mathrm{mg} / \mathrm{L}$, while temperature between $27.33 \pm 0.33^{\circ} \mathrm{C}-28.67 \pm 0.33^{\circ} \mathrm{C}$.

\section{Growth parameters and feed utilization}

Results on growth performance are presented in Table 4. Significant differences $(\mathrm{P}<0.05)$ were seen among the treatments in almost all growth indices expect for survival rate. Mean weight gain $(M W G)$ of the fishes differ significantly $(\mathrm{P}<0.05)$ from each other. D5 had the highest $M W G$ of $70.70 \pm 4.62 \mathrm{~g}$ which was significantly higher $(\mathrm{P}<0.05)$ than other treatments. This was followed by D4, $(54.72 \pm 4.40 \mathrm{~g})$, D3, $(44.66 \pm 3.38 \mathrm{~g}), \quad \mathrm{D} 1 \quad(42.14 \pm 2.31 \mathrm{~g})$ and D2 $(39.88 \pm 4.37 \mathrm{~g})$. The highest $F C R$ was recorded in D1 $(0.62 \pm 0.14)$ and the least value was observed in T5 $(0.54 \pm 0.04)$ which are not significantly different (P>0.05) from other treatments. SGR values differed significantly among the treatments $(\mathrm{P}<0.05)$. D5 had the highest $S G R$ of $5.06 \pm 0.10$ which differed significantly $(\mathrm{P}<0.05)$ from other treatments. This was followed by D4 $(4.63 \pm 0.15 \mathrm{~g})$ and D1 $(4.57 \pm 0.26 \mathrm{~g})$ respectively. D2 and D3 had the lowest with $S G R$ s $4.26 \pm 0.16$ and $4.27 \pm 0.08$ respectively. $P E R$ differed significantly among the treatments $(\mathrm{P}<0.05)$. D5 showed the highest $P E R$ of $5.06 \pm 0.10 \%$ being significantly $(\mathrm{P}<0.05)$ from the other diets. This was followed by D4 $(1.30 \pm 0.10 \%), \quad D 1$ $(1.24 \pm 0.20 \%), \quad \mathrm{D} 3 \quad(1.06 \pm 0.09 \%) \quad$ and $\mathrm{D} 2$ $(0.95 \pm 0.11 \%)$. There were no significant differences ( $\mathrm{P}>0.05)$ between PER values of D1, D2 and D3. There were no significant differences $(\mathrm{P}>0.05)$ in survival rates of the fish fed different inclusion levels of MSM. The highest survival rate was recorded in D2 $(96.67 \pm 3.33 \%)$ followed by D1 $(93.33 \pm 3.33 \%)$ and the least in D3 $(86.67 \pm 3.33 \%)$ and D4 $(86.67 \pm 6.67 \%)$. The final length of fish differed significantly with the highest in D5 $(25.03 \pm 1.04)$ and the least in D3 (19.27 \pm 0.64$)$.

\section{Discussion}

\section{Water Quality}

The values for physico-chemical parameters observed in current study were within the tolerance range of $C$. gariepinus (Table 3 ) and agree with the findings of Adekoya et al. (2004). Bhatnagar et al. (2004) reported that the levels of temperature as $\left(25-30^{\circ} \mathrm{C}\right)$ is ideal for culture of $C$. gariepinus. Adekoya et al. (2004) also recommended dissolved oxygen level of between $4-8 \mathrm{mg} / \mathrm{L}$. Bhatnagar et al.
(2004) reported dissolve oxygen level greater than 5 $\mathrm{mg} / \mathrm{L}$ support good fish production. Bhatnagar et al. (2004) also suggested that $1-3 \mathrm{mg} / \mathrm{L}$ has sublethal effect on growth and feed utilization; $0.3-0.8 \mathrm{mg} / \mathrm{L}$ is lethal to fishes and oxygen concentration above $14 \mathrm{mg} / \mathrm{l}$ is lethal to fish fry, and gas bubble disease may occur. Santhosh and Singh (2007) reported that the suitable $\mathrm{pH}$ range for fish culture is between 6.7 and 9.5 and ideal $\mathrm{pH}$ level is between 7.5 and 8.5 and above and below this could be stressful to the fishes.

\section{Growth Performance}

The present study investigated the effect of replacement of maize with $M S M$ on the growth performance and feed utilization of African catfish (C. gariepinus). Among the diets, T5 (100\% MSM) recorded the best growth performance which reflected in the values obtained for $M F W G, F C R$, $S G R$, and PER (Table 4). While T5 (100\% MSM) recorded the highest weight gain, lowest $F C R$, highest $S G R$ and the highest $P E R$ among the experimental diets, this result collaborates the findings of Iheanacho et al. (2017) who reported increased growth when Nile tilapia (Oreochromis niloticus) juveniles were fed melon seed peel based diet in 56 days feeding trial. Orire and Ricketts (2013) reported better growth performance and feed utilization efficiency when $O$. niloticus were fed melon seed peel based diet. Nwanna et al. (2009) reported poor feed utilization of potato peel based diet as dietary carbohydrate source in the diet of $C$. gariepinus. The findings of the present study differ from the report made by Jesu et al. (2008) on the utilization of various dietary carbohydrate levels by the freshwater catfish Mystus montanus. The disagreement may be due to the higher protein content of MSM (14.88\%) when compared to $8.11 \%$ in potato peel. Values for FCR, MFWG, SGR, PER and mortality) were optimal and similar to the result reported by Amanat and Nasser (2001). Diet 2 (25\% $M S M$ ) recorded the poorest growth response indicating poor feed utilization by the fish. This was expressed in the values of its biological evaluation such as high $F C R$, low $M W G, S G R$ and $P E R$ values (Table 4). The results of this study disagree with the observation made by Nwanna et al. (2009), who reported that very high inclusion levels of unconventional dietary carbohydrate sources often result in poor performance of the fish. The growth response of the control diet (T1,0\%MSM) was the second to least which was in agreement with the reports of Solomon et al. (2007) and Nwanna et al. (2009). Fagbenro et al. (2000) reported a comparable performance of Acha (Digitaria exilix) meal with maize and sorghum meal as dietary carbohydrate source for Nile tilapia. Nwanna (2003) showed the 
Table 4. Growth performance of C. gariepinus fingerling fed graded level of melon shell based

\begin{tabular}{lccccc}
\hline Parameter & $\mathrm{D} 1$ & $\mathrm{D} 2$ & $\mathrm{D} 3$ & $\mathrm{D} 4$ & $\mathrm{D} 5$ \\
\hline$I W(\mathrm{~g})$ & $3.50 \pm 0.09^{\mathrm{a}}$ & $3.45 \pm 0.03^{\mathrm{a}}$ & $3.70 \pm 0.47^{\mathrm{a}}$ & $3.61 \pm 0.17^{\mathrm{a}}$ & $3.57 \pm 0.21^{\mathrm{a}}$ \\
$I L(\mathrm{~cm})$ & $6.30 \pm 0.15^{\mathrm{b}}$ & $6.13 \pm 0.12^{\mathrm{b}}$ & $7.00 \pm 0.35^{\mathrm{ab}}$ & $6.80 \pm 0.40^{\mathrm{ab}}$ & $7.07 \pm 0.12^{\mathrm{a}}$ \\
$F W(\mathrm{~g})$ & $46.57 \pm 1.74^{\mathrm{bc}}$ & $43.33 \pm 4.40^{\mathrm{c}}$ & $48.38 \pm 3.97^{\mathrm{bc}}$ & $58.33 \pm 4.41^{\mathrm{b}}$ & $74.27 \pm 4.74^{\mathrm{a}}$ \\
$F L(\mathrm{~cm})$ & $22.00 \pm 0.84^{\mathrm{b}}$ & $21.80 \pm 0.25^{\mathrm{bc}}$ & $19.27 \pm 0.64^{\mathrm{c}}$ & $22.40 \pm 1.00^{\mathrm{b}}$ & $25.03 \pm 1.04^{\mathrm{a}}$ \\
$M W G(\mathrm{~g})$ & $42.14 \pm 2.31^{\mathrm{bc}}$ & $39.88 \pm 4.37^{\mathrm{c}}$ & $44.66 \pm 3.83^{\mathrm{bc}}$ & $54.72 \pm 4.40^{\mathrm{b}}$ & $70.70 \pm 4.62^{\mathrm{a}}$ \\
$F C R$ & $0.62 \pm 0.14^{\mathrm{a}}$ & $0.60 \pm 0.02^{\mathrm{a}}$ & $0.59 \pm 0.07^{\mathrm{a}}$ & $0.55 \pm 0.16^{\mathrm{a}}$ & $0.54 \pm 0.04^{\mathrm{a}}$ \\
$P E R(\%)$ & $1.24 \pm 0.20^{\mathrm{b}}$ & $0.95 \pm 0.11^{\mathrm{b}}$ & $1.06 \pm 0.09^{\mathrm{b}}$ & $1.30 \pm 0.10^{\mathrm{ab}}$ & $1.68 \pm 0.11^{\mathrm{a}}$ \\
$S G R(\% /$ day $)$ & $4.57 \pm 0.26^{\mathrm{ab}}$ & $4.20 \pm 0.16^{\mathrm{b}}$ & $4.27 \pm 0.08^{\mathrm{b}}$ & $4.63 \pm 0.15^{\mathrm{ab}}$ & $5.06 \pm 0.10^{\mathrm{a}}$ \\
Survival rate $(\%)$ & $93.33 \pm 3.33^{\mathrm{a}}$ & $96.67 \pm 3.33^{\mathrm{a}}$ & $86.67 \pm 3.33^{\mathrm{a}}$ & $86.67 \pm 6.67^{\mathrm{a}}$ & $90.00 \pm 0.00^{\mathrm{a}}$ \\
\hline
\end{tabular}

Means within rows with different superscripts are significantly different $(\mathrm{P}<0.05)$.

$I W=$ Initial weight, $I L=$ Initial length, $F W=$ Final weight, $F L=$ Final length,$M W G=$ Mean weight gain, $F C R=$ Food conversion ratio, $P E R=$ Protein efficiency ratio, $S G R=$ Specific growth rate.

effectiveness of replacing maize with acha in the diets of Nile tilapia (Oreochromis niloticus). Nwanna et al. (2004) also reported that replacing maize with a non-conventional carbohydrate source tamarind (Tamarindus indica) resulted in good growth performance of catfish and improved economic returns.

Our results showed that $C$. gariepinus effectively utilized feed formulated with different dietary inclusion levels of $M S M$ based diet especially diet 5 (100\% MSM). This implies that MSM is an agro waste product to efficiently replace maize as carbohydrate source in the diet of Clarias gariepinus. Fish farmers are encouraged to explore this opportunity as it will reduce drastically the cost of fish production and enhance growth of fish as well.

\section{Acknowledgements}

Authors are grateful to Oluchi Umah for typesetting the manuscript.

\section{References}

A.O.A.C. 2000. Official methods of analysis of AOAC. International $17^{\text {th }}$ edition; Gaithersburg, MD, USA, $19 \mathrm{p}$.

Abiodun OA, Adeleke RO. 2010. Comparative studies on nutritional composition of four melon seeds varieties. Pakistan J Nutr. 9(9): 905-908.

Adekoya RA, Awojobi HA, Taiwo BBA. 2004. The effect of partial replacement of maize with full fat palm kernel on the performance of laying hens. J Agric Forest Soc Sci. 2(2): 89-94. doi:10.4314/joafss.v2i2.33696

Akinrotimi OA, Gabriel UU, Owhonda NK, Onukwo DN, Opara JY. 2007. Formulating an environmentally friendly fish feed for sustainable aquaculture development in Niger. Agric J. 2(5):606-612.

Amanat A, Nasser AA. 2001. Effect of feeding different carbohydrate to lipid ratios on the growth performance and body composition of Nile Tilapia (Oreochromis niloticus) fingerlings. Anim Res. 50(1): 91-100. doi:10.1051/animres:2001119

Baruah K, Sahu NP, Debnath D. 2003. Dietary phytase: An ideal approach for a Cost effective and low polluting aqua-feed. NAGA, 27(3):15-19.
Bhatnagar A, Jana SN, Garg, SK, Patra BC, Singh G, Barman UK. 2004. Water quality management in aquaculture, In: Course Manual of summer school on development of sustainable aquaculture technology in fresh and saline waters, CCS Haryana Agricultural, Hisar (India), 203- 210 pp.

De Silva SS, Anderson TA. 1995. Fish nutrition in aquaculture. Chapman \& Hall Aquaculture Series 1. New York:Chapman \& Hall, 319 p.

Duncan DB. 1955. Multiple range and multiple F-test Biometrics 11(1):1-42 doi: $10.2307 / 3001478$

Eyo AA. 2005. Management of inland capture fisheries and challenges of fish production in Nigeria. Paper presented at: $19^{\text {th }}$ Annual Conference of the Fisheries Society of Nigeria (FISON); Ilorin, Nigeria.

Fagbenro OA, Smith MAK, Amoo AI. 2000. Acha (Digitaria exilis Stapf) meal compared with maize and sorghum meals as a dietary carbonhydrate source for Nile tilapia (Oreochromis niloticus L.). Isr J AquacultBamid. 52(1):3-10

Fagbohun ED, Lawal OU, Hassan OA. 2011. The chemical composition and mycoflora of sundried shelled melon seeds (Citrullus vulgaris) during storage, Int R JMicrobiol. 2(8): 310-314.

FAO 2004. The state of world fisheries and aquaculture. Food and Agriculture Organization, United Nations. Rome $59 \mathrm{pp}$.

FAO 2005. Further processing of fish. Fisheries and aquaculture department, Rome. Updated 27 May 2005, $78 \mathrm{pp}$.

FAO 2006. State of world aquaculture. FAO Fisheries Technical paper, No. 500. Rome, 134pp.

Iheanacho SC, Ogunji JO, Ogueji EO, Nwuba LA, Nnatuanya IO, Ochang SN, Mbah CE, Usman IB, Haruna M. 2017. Comparative assessment of ampicillin antibiotic and ginger (Zingiber officinale) effects on growth, haematology and biochemical enzymes of Clarias gariepinus Juvenile. J Pharma Phytochem. 6(3): 761-767.

Iheanacho SC, Ikwo TN, Igweze N, Chukwuidha C, Ogueji EO, Onyeneke R. 2018. Effect of different dietary inclusion levels of melon seed (Citrullus lanatus) peel on growth, haematology and histology of Oroechromis niloticus juvenile. Turk J Fish Aquat Sc. $18(3)$ : 377-384.

doi :10.4194/1303-2712-v18_3_03 
Jamiu DM, Ayinla OA. 2003. Potantial for the development of aquaculture in Africa. NAGA 26 (3): 9-13.

Jesu AA, Muruganandam M, Marimuthu K, Haniffa MA. 2008. utilization of carbohydrates as a dietary energy source by striped murrel Channa striatus (bloch) fingerlings. Centre for Aquaculture Research and Extension (CARE) St. Xaviers College (Autonomous), Palayamkottai Tamilnadu-627 002, India.

Moerman D. 1998. Native American ethnobotany. Oregon:Timber Press 927 p.

Nwana MB. 2003. Feed and feeding of fish and shrimp: A manual on the preparation and presentation of compound feeds, 14-18 December 1992. Bangkok, Thailand.

Nwanna L, Fagbenro O, Olanipekun S. 2004. Evaluation of tamarind (Tamarindus indica) seed meal as a dietary carbohydrate for the production of Nile tilapia Oreochromis niloticus (L). Anim R Int 1(3): $164-168$.

Nwanna LC1, Falaye AE, Olarewaju1OJ, Oludapo1 BV. 2009. Evaluation of Nile tilapia (Oreochromis niloticus 1 ) fed dietary potato peels as replacement for yellow maize. Paper presented at: $24^{\text {th }}$ Annual Conference of the Fisheries Society of Nigeria (FISON); Akure, Nigeria.

Ogbe AO, George GAL. 2012. Nutritional and antinutrient composition of melon husks: Potential as feed ingredient in poultry diet. Res J Chem Sci. 2(2): 3539.

Ogunji JO. 2004. Alternative protein source in diets for farmed Tilapia. Animal Science Comparative Reviews Number 13; CAB International Publishing (Oxford, UK). Nutr Abstr and Rev 74(8): 23-32.

Olatunde A. 1996. Digestive enzymes in alimentary tract of Clarias lazera (Cuvier and Vaenciennes); family Clariidae (Osteichthys: Siluriformes). Archives fur hydrobiology. 112: 107 -113pp.

Olurin KB, Olojo EAA, Olukoya OA. 2006. Growth of African catfish Clarias gariepinus fingerlings, fed different levels of cassava. Int Digi Org Sci Info. 1(1): 54-56.

Orire AM, Ricketts OA. 2013. Utilisation of Melon shell as dietary energy source in the diet of Nile Tilapia (Oreochromis niloticus) Int J Eng Sci. 2 (4): 05-11.

Santhosh B, Singh NP. 2007. Guidelines for water quality management for fish culture in Tripura, ICAR Research Complex for NEH Region, Tripura Center, Publication no.29

Solomon SG, Tiamiyu LO, Agaba UJ. 2007. Effect of feeding different grain sources on the growth performance and body composition of Tilapia, (Oreochromis niloticus) Fingerlings Fed in Outdoor Hapas. 6(3):271-275 doi: 10.3923/pjn.2007.271.275

Tewe OO. 2004. Cassava for livestock feed in sub-sahara Africa. FAO. Rome Italy. 64 p. 